\title{
下顎を偏位させた際のラット下顎頭軟骨の反応
}

\author{
今 村 正史 \\ 東京医科歯科大学歯学部矯正学教室（指導 : 三浦不二夫教授）
}

（昭和48年10月 29 日受付）

\section{Cellular Responses of Condylar Cartilage Induced by Mandibular Displacement in Rats}

\author{
Masafumi Imamura \\ Department of Orthodontics School of Dentistry \\ Tokyo Medical and Dental University \\ (Director: Prof. Fujio Miura)
}

要旨 : 幼若ラット, 成熟ラットの下顎切歯唇面に斜面板を装着し, その結果誘起させる下筫遠心咬合に対 して, 下䫟頭軟骨がどのように反応するかについて定量的に検討した。すなわち, ${ }^{3} \mathrm{H}$-thymidine, ${ }^{3} \mathrm{H}$-proline を用いたオートラジオグラフィー, ならびに HE 染色標本により, 軟骨細胞数, 軟骨層厚径, 軟骨細胞増 殖，軟骨基質形成，軟骨基質吸収の各々について検討を加え，次のような結果が得られた。

1. 幼若, 成熟個体ともに，斜面板による外的刺激を与えた場合には，下頡頭軟骨における細胞数は，わ ずかな減少を示したが全般に大きな変動は認められなかった。

2. 外的刺激を受けた場合の下頡頭軟骨の各層の厚径は,幼若個体では著しい減少がみられ,とくに hypertrophic zone で顕著であった。しかし, transitional zone の厚径には余り変動がなかった。一方, 成熟個 体の厚径は hypertrophic zone に減少がわずかに観察されたにすぎず，ほとんど変動しなかった。

3. 下蕦頭軟骨の標識指数は, 幼若個体では下䪽頭軟骨の中央部および後方部で著しい低下を認めたのに 対し, 成熟個体では中央部に低下を認めたが, 幼若個体にみられたような大幅な低下はなかった。

4. 外的刺激は, 軟骨細胞分裂のみならず, 軟骨基質形成にも多大の影響を与えた。すなわち, 軟骨に取 込まれた ${ }^{3} \mathrm{H}$-proline による銀粒子数は, 幼若個体では全領域で著しく減少し, 基質内線維形成の低下を示 した。成熟個体では後方部で減少が観察されたのみで, 幼若個体のような大きな変動はなかった。

5. Erosion zone において軟骨の吸収に関与していると思われる chondroclast の出現数は, 幼若個体, 成熟個体ともに減少した。

6. 成熟個体は幼若個体に比し, 細胞増殖, 基質形成, 基質吸収のすべての面で活性が著しく低下してお り，外的刺激に対する反応は幼若個体と同様に低下を示したが，その変動量は僅少であった。

\section{I. 緒 言}

下顎頭が下顎の成長発育に重要な役割を果して いることは古くから指摘されているところであ りそそれだけに下䪽頭に関する実験的研究も数多 w。
Furstman (1965) ${ }^{1)}$ は, ラット田歯を抜歯して咬 合を変化させた場合に，下顎頭に軟骨層の肥厚と osteosclerosis を観察し，下頡頭が咬合の変化に 対し敏感に反応することを指摘している。Stöckli and Willert $(1971)^{2)}$ は，サルに下顎近心咬合を 誘起させた際に，下顎頭後方部での軟骨の肥厚を 
観察して，下顎頭軟骨の細胞動態と下顎頭の成長 方向とは，外的刺激による影響を受けやすく，こ の部は, 代償性組織順応性 (compensating tissue adaptation）の高い potentiality を有すると述べ ている。また, Lemoine ら (1968) $)^{3)}$ も，ラット 下顎を右側に偏位させることにより，左側の下顎 頭軟骨の prechondroblastic zone および chondroblastic zone の厚さが増大し，かつ，すでに 化骨した部分での骨改造機転が活発となっている 像を示して，成長過程の下顎頭軟骨が外的刺激に より容易に影響を受けると結論している。

しかしながら，外的刺激が果して下顎頭におけ る細胞活性にどのような影響を与えるかについて は，必ずしも十分に把握されていない。

幸い，細胞活性を検討する手段として，ラジオ アイソトープを利用する方法が近年出現してから は，下顎頭に関する研究にも活用され始めてき た。

下顎頭の成長に関して Blackwood (1966) ${ }^{4}$ は, ${ }^{3} \mathrm{H}$-thymidine を用いたオートラジオグラフィー により，ラット下顎頭軟骨細胞の life span を測 定した。また，Kanouse ら (1969) ${ }^{5)}$ は，サルの 下顎頭軟骨の intermediate zone における標識指 数が増齢と共に低下寸ることを報告している。

一方，下顎頭の外的刺激に対する細胞レベルで の反応については, Folke and Stallard (1966) ${ }^{6)}$ は, ラットに斜面板を用いて下顎遠心咬合を誘起させ た際に，個体の成熟度の如何にかかわらず下嚬 頭軟骨の embryonic zone における標識指数が変 動することを認めたことから，この層が生涯存続 し，かつ成熟個体においてさえも，この層の増殖 活性を賦活することが可能であると述べている。 また，野口 $(1970)^{7)}$, Charlier ら(1969) ${ }^{8)}$ も，下 顎頭に外力を加えた際に，軟骨細胞の life span および, 標識指数の変動を認め, 外力が下顎頭軟 骨細胞の増殖活性や，その動態に変動を与え得る ことを報告した。

しかしながら，これらの研究は, 外的刺激が軟骨 細胞の一連の分化成熟過程にどのような 影響を与 ているかについては，必ずしも定量的に詳細に把
握しているとはいえない。

そこで，本研究においては，幼若，ならびに成 熟ラットを用い，下頡頭軟骨に抢ける細胞数，厚 径，細胞増殖，基質形成，および基質吸収の各々 について，HE 染色，オートラジオグラフィーを 併用した定量的検討を行ない，得られた結果か ら，下顎頭軟骨各層の成長発育に関する役割やそ の意義を把握し，さらに斜面板により下顎遠心咬 合を誘起させた場合の下顎頭軟骨の反応様式につ いて検討することとした。

\section{II. 実験方法}

雌性の Wistar 系幼若ラット（生後25日，体重 約 $50 \mathrm{~g}$ )，および成熟ラット（生後 4 力月，体重約 $230 \mathrm{~g}$ ）計55匹を，対照群と実験群とに分け，さら にそれぞれの群をアイソトープ投与群と非投与群 とに区分した。

実験群の各ラットには，下顎遠心咬合を誘導さ せるために，下顎切歯唇面に斜面板を 10 日間装着 した。装着後10日目にアイソトープ 投与群をさら に A, B の 2 群に分け，A群に対しては ${ }^{3} \mathrm{H}$-thymidineを，B群に対しては ${ }^{3} \mathrm{H}$-proline をそれ ぞれ腹腔内投与し，アイソトープ 投与 1 時間後に 全動物を断頭した。

1. 装置（図 1, 2)

近年開発されたダイレクトボンディング 法を応 用し，オウロパンソーダ麻酔下のラット下䇗切歯 唇面に即重レジンを接着, 添加し，咬合の際，下 顎が遠心に変位しうるに十分な 傾斜をもつ斜面板 を形成した。なお，上顎切歯と接触する斜面部に は，レジンの咬耗を防ぐために，矯正用レクトア ンギュラーワイヤーが埋め込まれた。

\section{2. ラットの頭部 $\mathrm{X}$ 線規格写真撮影}

斜面板装着後の枵顔面頭蓋の形態上の変化を検 討するために，花田 ${ }^{9)}$ のラット用頭部 X線規格写 真撮影法を用い，装置装着前と，装着後10日目の ラット頭部の $\mathrm{X}$ 線撮影を行なった。

3. オートラジオグラムの作製

アイソトープ投与群のうち， A 群の 各動物には ${ }^{3} \mathrm{H}$-thymidine 溶液（比放射能 $5.0 \mathrm{Ci} / \mathrm{mM}$ ， the 


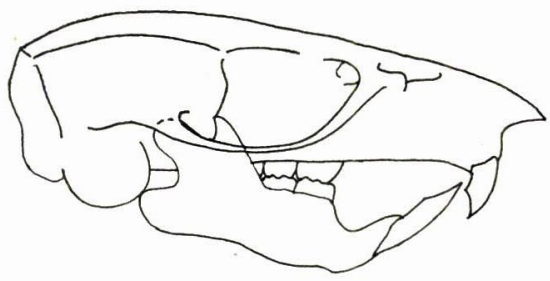

A

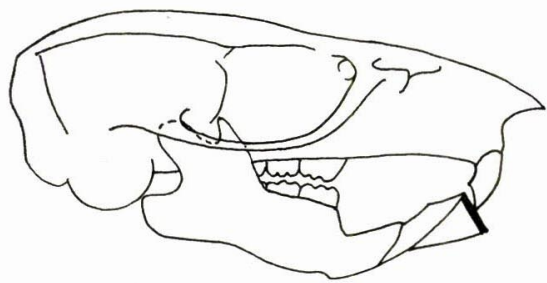

(pH 7.0) で 3 日間固定し，ついで $10 \%$ EDTA$2 \mathrm{Na}$ （pH 7.0）で20日間脱灰した後，パラフィ ン包埋を行なった。ひきつゔき $5 \mu$ の厚さで下頡 頭の正中矢状断連続切片を作製した。各パラフィ ン切片は, dipping 法により, サクラ乳剂 NR-M 2 (小西六写真工業株式会社製) に浸漬され，冷 蔵厙内 $\left(4^{\circ} \mathrm{C}\right)$ に60日間保存された。現象はコニド 一ルX (小西六写真工業株式会社製) で $18^{\circ} \mathrm{C}, 4$ 分間行ない，定着はコニフィックス・X（小西六 写真工業株式会社製) で $18^{\circ} \mathrm{C} ， 7$ 分間行なった。 ついで, 30 分の水洗の後, ヘマトキシリン単染色 を施した。また，アイソトープ非投与群の各切片 は，バックグラウンド補正用標本と, HE 染色標 本の作製に供した。

4. 分析方法について（図 3)

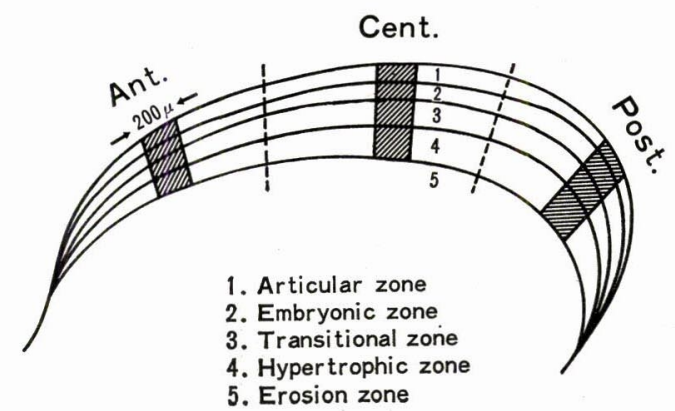

図 3 計測部位. 斜線部分は計測部位を示す

各組織標本について，下顎頭軟骨における軟骨 細胞の活性, すなわち細胞増殖や軟骨基質の変化 を観察するために次のような事項について計測を 行なった。

計測にあたっては，野口7) の報告に従って下靧 頭軟骨組織の表層より, articular zone, embryonic zone, transitional zone, hypertrophic zone,

図 2 ラット下顎切歯に装着された斜面板

Radiochemical Centre, Amersham, England) を体重 $1 \mathrm{~g}$ 当り $1.0 \mu \mathrm{Ci}, \mathrm{B}$ 群の各動物には ${ }^{3} \mathrm{H}$ proline 溶液（比放射能 $63.0 \mathrm{Ci} / \mathrm{mM}$, the Radiochemical Centre, Amersham, England) を 体重 $1 \mathrm{~g}$ 当り $3 \mu \mathrm{Ci}$ ，それぞれ断頭 1 時間前に腹 腔内注射した。

断頭後，各動物の 頭部を $10 \%$ 中性フォルマリン erosion zone の 5 層に分け，さらにそれぞれを前 方部，中央部，後方部の 3 領域に区分し取扱い, 各層の各領域について, その中央を幅 $200 \mu$ にわ たって次の項目を算出した。

(1) 軟骨細胞数

(2) 軟骨各層の厚径

(3) ${ }^{3} \mathrm{H}$-thymidine による標識指数

(4) ${ }^{3} \mathrm{H}$-proline の取り込みを示す銀粒子数 
また，軟骨吸収に対しては， erosion zone にお ける各領域の全面にわたる chondroclast の総数 を算定した。

なお, ${ }^{3} \mathrm{H}$-thymidine の 標識指数算出の際にバ ックグラウンド補正は千葉 ${ }^{10)}$ の方法に従った。ま た, ${ }^{3} \mathrm{H}$-proline 投与によって得られたオートラジ オグラム上のバックグラウンドの補正は，アイソ トープ非投与群のオートラジオグラムより得られ たバックグラウンド算定数を差し引いて行なっ た。

\section{III. 実験結果}

\section{1. 実験動物の体重の変動（図 4)}

幼若個体では実験期間中の体重増加量は, 対照 群と実験群との間に有意の差は認められず，両群 共に同様な増加傾向を示した。一方，成熟個体実 験群に抢いては, 装置装着後, 体重増加は認めら れず対照群との差がしだいに大きくなり，10日後

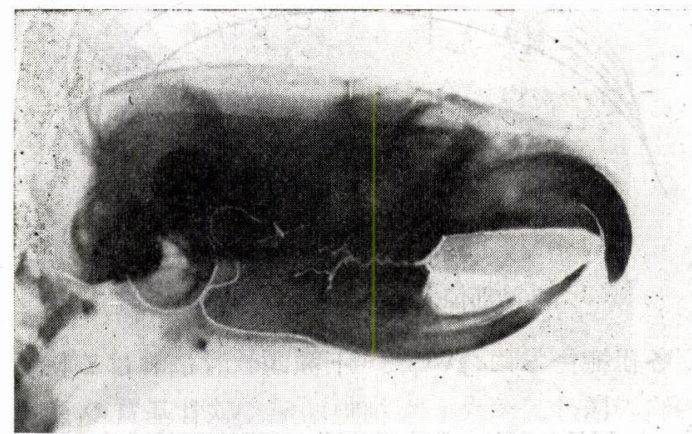

A

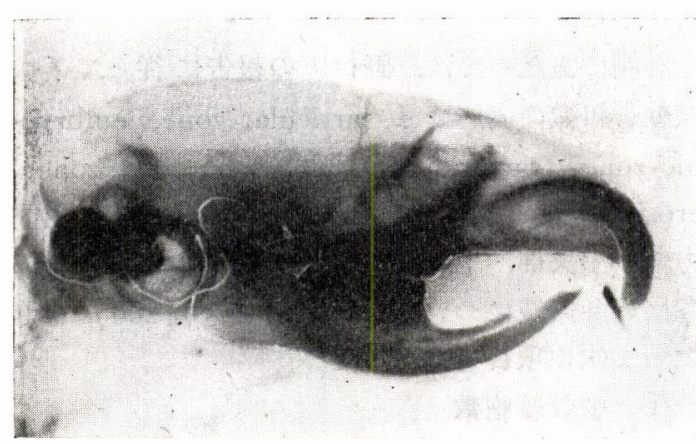

$\mathrm{A}^{\prime}$

\section{Body Weight}

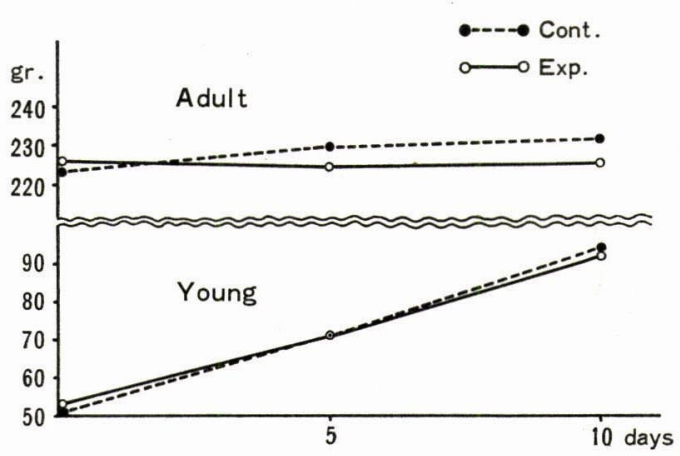

図 4 実験期間中における実験動物の体重変動

ではその差が $5 \sim 7 \mathrm{~g}$ になった。

2. 頭部X線規格写真による 所見（図 5，6 )

装置装着前の頭部X線規格写真と, 装置装着後 10 日目のそれの 1 例を図 5 に示す。図で知られる ように, 幼若個体, 成熟個体共に全ての例で 10 日

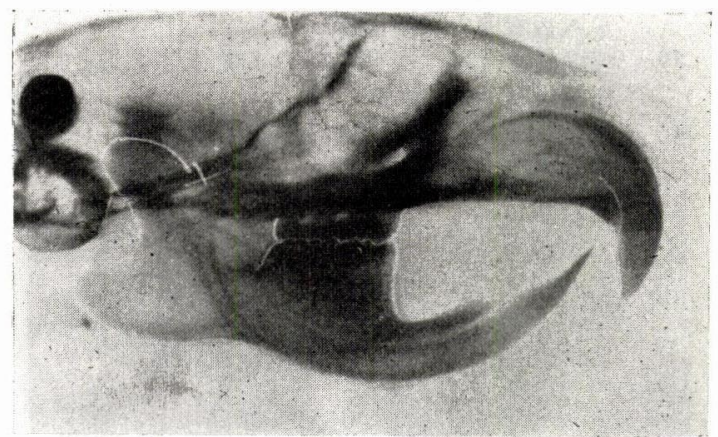

B

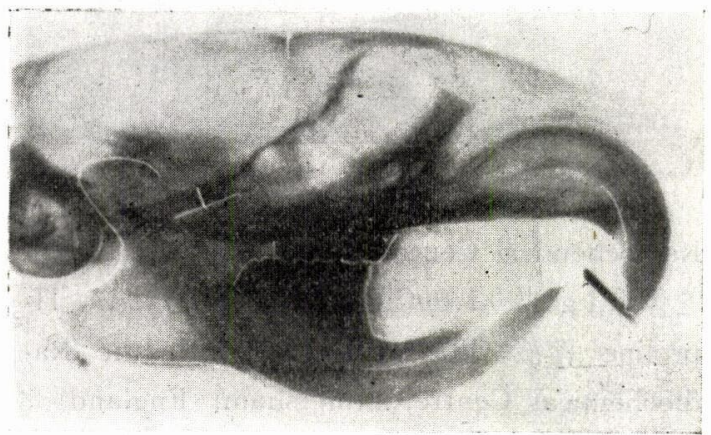

$\mathrm{B}^{\prime}$

図 5 ラットの頭部 $\mathrm{X}$ 線規格写真

$\mathrm{A}, \mathrm{B}$ は, 幼若, 成熟ラットの装置装着前の写真を示し, $\mathrm{A}^{\prime}, \mathrm{B}^{\prime}$ は, 各々の装置装着後10日目のものを示す 

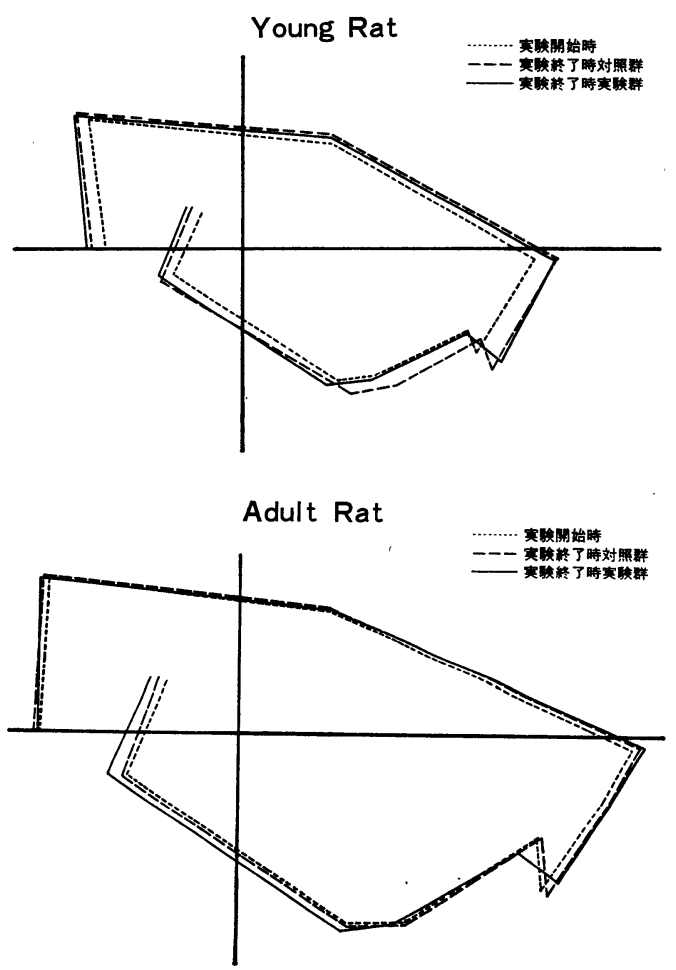

図 6 ラットのプロフィログラム上で観察され た変化

後のものでは前歯部 over jet の増大と臼歯咬合 関係に変化が認められ，下顎が遠心位に誘導され ていることがわかる。

装置装着前後のX線写真を花田による計測方法 を用い比較検討したところ，図 6 に示されるよう な変化が認められた。すなわち，幼若個体実験群 においては，10日間の実験期間中，上顎は対照群 とほとんど同じ成長をしたのに対し，下顎は，そ の前方部が装置装着前とほぼ同じ位置に留まって おり，従って著しい over jet の増大が認められ た。しかし，下顎の後方部は10日後でほぼ対照群 のそれと同じ位置を占めていた。

一方，成熟個体においては，対照群，実験群共 に上下䪹の成長はほとんどみられず，単に，実験 群における下顎全体の著明な 後方変位が 認めら れ，その結果として著しい over jet が認められ た。つまり，誘起された over jet は幼若，成熟 個体共にほぼ同じ程度のものであった。

\section{Number of Cells}

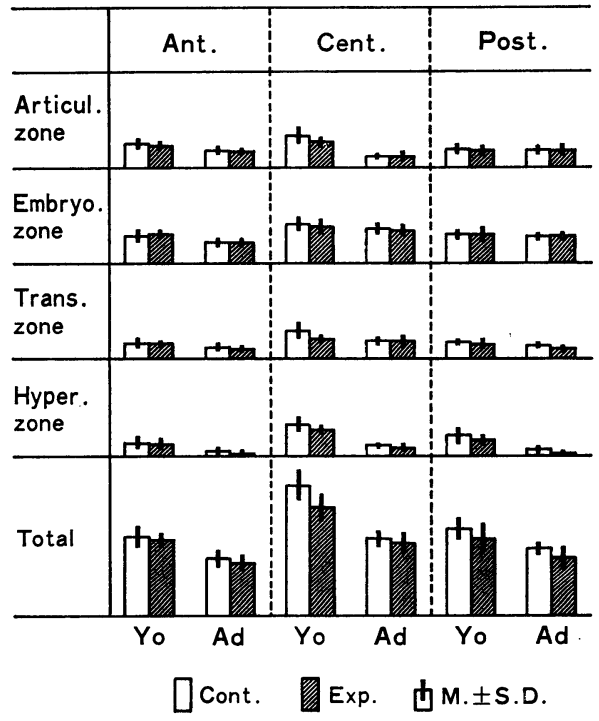

図 7 下顎頭軟骨各層における細胞数の変動

3. 下顎頭軟骨における細胞活性

1）幼若ならびに成熟個体対照群における所見

a. 軟骨細胞数（図 7，表 1)

図ならびに表に示したように，幼若，成熟個体 共に中央部の細胞総数が全領域中最も多く，また 各軟骨層のうちでは embryonic zone が最も細胞 数に富んでいた。しかし，成熟個体では幼若個体 に比して，中央部での細胞総数が著しく減少し， 3 領域の細胞数の平均化が認められる。また, 各 軟骨層のうちでは, hypertrophic zone 中の細胞 数に著明な減少が認められたが，他層での変動は わずかであった。

b. 軟骨層厚径（図 8 ，表 2 ）

幼若個体においては，図と表で知られるように 深層に向からほど厚径は増大し, hypertrophic zone が最も厚く，とくに中央部，後方部では全 軟骨層厚径のほぼ50\%を占めていた。成熟個体で は transitional zone が最大の厚径を示し, 幼若 個体に比して, hypertrophic zone の厚径の著し い減少が目立った。

また, 幼若, 成熟個体両者共, 軟骨層厚径は中 央部が最も厚く，次いで後方部，前方部の順とな 
表 1 軟骨各層における細胞数の変動 標本数 $=10$

\begin{tabular}{l|c|c|c|c|c|c|c}
\hline \multirow{2}{*}{} & & \multicolumn{3}{|c|}{ YOUNG } & \multicolumn{3}{c}{ ADULT } \\
\cline { 3 - 9 } & & Ant. & Cent. & Post. & Ant. & Cent. & Post. \\
\hline \multirow{2}{*}{$\begin{array}{l}\text { Articul. } \\
\text { zone }\end{array}$} & Co. & $76.5 \pm 16.3$ & $101.0 \pm 26.5$ & $62.7 \pm 15.5$ & $57.1 \pm 10.6$ & $38.7 \pm 8.8$ & $58.4 \pm 14.6$ \\
Ex. & $72.0 \pm 13.6$ & $81.7 \pm 16.1$ & $55.1 \pm 13.9$ & $56.4 \pm 9.6$ & $40.5 \pm 14.3$ & $58.4 \pm 20.2$ \\
\hline Embryo. & Co. & $87.9 \pm 19.1$ & $123.4 \pm 21.7$ & $93.1 \pm 12.5$ & $67.6 \pm 16.0$ & $110.4 \pm 19.4$ & $82.3 \pm 17.6$ \\
zone & Ex. & $89.7 \pm 12.6$ & $113.9 \pm 26.1$ & $92.9 \pm 23.8$ & $67.2 \pm 14.3$ & $104.8 \pm 18.7$ & $84.3 \pm 12.7$ \\
\hline Trans. & Co. & $47.5 \pm 15.6$ & $88.4 \pm 26.9$ & $53.4 \pm 8.0$ & $37.5 \pm 10.2$ & $57.3 \pm 15.4$ & $42.2 \pm 5.1$ \\
zone & Ex. & $48.2 \pm 7.9$ & $63.0 \pm 11.7 *$ & $44.7 \pm 16.0$ & $31.7 \pm 7.2$ & $56.4 \pm 20.7$ & $31.5 \pm 12.9 *$ \\
\hline Hyper. & Co. & $39.1 \pm 15.6$ & $98.7 \pm 23.6$ & $64.8 \pm 25.2$ & $17.8 \pm 9.2$ & $36.7 \pm 9.2$ & $25.5 \pm 8.0$ \\
zone & Ex. & $29.1 \pm 14.7$ & $80.8 \pm 16.1$ & $49.5 \pm 13.9$ & $9.1 \pm 11.1$ & $26.6 \pm 13.6$ & $8.4 \pm 9.7 *$ \\
\hline \multirow{2}{*}{ Total } & Co. & $251.0 \pm 37.3$ & $411.5 \pm 50.7$ & $274.0 \pm 33.8$ & $180.0 \pm 26.7$ & $243.1 \pm 31.8$ & $208.4 \pm 22.4$ \\
& Ex. & $239.0 \pm 21.9$ & $339.4 \pm 40.4 *$ & $242.2 \pm 49.7$ & $164.4 \pm 22.7$ & $228.3 \pm 37.5$ & $182.6 \pm 38.6$
\end{tabular}

* 危険率 $5 \%$ で有意 数字は M. \pm S.D.

ThICKNESS OF CARTILAGE

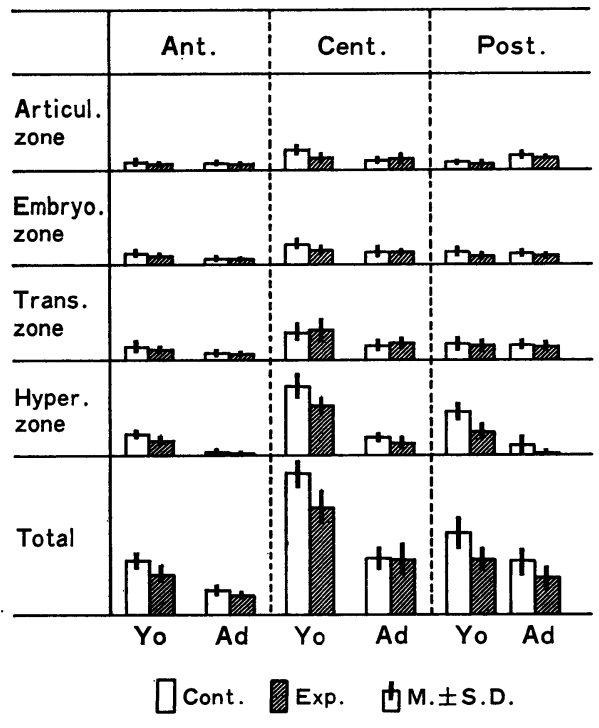

図 8 下顎頭軟骨各層における厚径の変動

る。成熟個体においては中央部の減少が著しく, 後方部とほぼ同じ厚径を持つようになり，細胞数 と同様， 3 領域間の平均化の 傾向がみられた。

C. ${ }^{3} \mathrm{H}$-thymidine による標識指数 (図 9,10 , 表 3 )

${ }^{3} \mathrm{H}$-thymidine 投与 1 時間後の 標識細胞は，図
で示すように，その大多数が embryonic zone に 限局して観察され, transitional zone, articular zone にもごくわずかに認められたが， hypertrophic zone には皆無であった。

幼若個体の標識指数は, 中央部で最も高く, 次 いで後方部がつゔき，前方部では最も低かった が，成熟個体のそれは，後方部，中央部，前方部 の順に低くなっており，幼若個体に比べ，全領域 で標識指数の著しい低下が認められた。

d. ${ }^{3} \mathrm{H}$-proline 取込みによる 銀粒子数（図11, 12，表 4)

${ }^{3} \mathrm{H}$-proline 投与 1 時間後には，その取込みを示 す銀粒子は図11に示すように，軟骨細胞内，およ び基質中に多数みられた。

幼若個体，成熟個体共，銀粒子数は領域別には 中央部で最も多く, 後方部, 前方部と続いており, 層別には transitional zone に最も多く, さらに embryonic zone, hypertrophic zone, articular zone の順に少なくなっており， articular zone には銀粒子がほとんど観察されなかった。なお， transitional zone 中に含まれる銀粒子数は総銀粒 子数の 60 70\%を占めていることが示された。

一方, 成熟個体は幼若個体に比べると, 各領 域, 各層で銀粒子数の減少がみられたが，中央部 
表 2 軟骨各層の厚径の変動 標本数 $=10$

\begin{tabular}{|c|c|c|c|c|c|c|c|}
\hline & & \multicolumn{3}{|c|}{ YOUNG } & \multicolumn{3}{|c|}{ ADULT } \\
\hline & & Ant. & Cent. & Post. & Ant. & Cent. & Post. \\
\hline $\begin{array}{l}\text { Articul. } \\
\text { zone }\end{array}$ & $\begin{array}{l}\text { Co. } \\
\text { Ex. }\end{array}$ & $\begin{array}{l}25.0 \pm 7.1 \\
19.0 \pm 5.2^{*}\end{array}$ & $\begin{array}{l}64.0 \pm 17.8 \\
35.5 \pm 10.4^{* *}\end{array}$ & $\begin{array}{l}27.0 \pm 4.2 \\
20.5 \pm 8.9\end{array}$ & $\begin{array}{l}22.0 \pm 2.6 \\
17.5 \pm 4.2^{*}\end{array}$ & $\begin{array}{l}32.0 \pm 10.1 \\
36.0 \pm 12.9\end{array}$ & $\begin{array}{l}44.0 \pm 10.5 \\
38.0 \pm 7.1\end{array}$ \\
\hline $\begin{array}{l}\text { Embryo. } \\
\text { zone }\end{array}$ & $\begin{array}{l}\text { Co. } \\
\text { Ex. }\end{array}$ & $\begin{array}{l}37.5 \pm 8.6 \\
25.5 \pm 6.4^{*}\end{array}$ & $\begin{array}{l}64.0 \pm 15.1 \\
45.5 \pm 13.2^{*}\end{array}$ & $\begin{array}{l}39.5 \pm 11.2 \\
28.5 \pm 8.8^{*}\end{array}$ & $\begin{array}{l}22.5 \pm 4.9 \\
19.5 \pm 6.0\end{array}$ & $\begin{array}{l}42.5 \pm 13.4 \\
41.5 \pm 2.4\end{array}$ & $\begin{array}{l}37.0 \pm 10.1 \\
29.0 \pm 8.1\end{array}$ \\
\hline $\begin{array}{l}\text { Trans. } \\
\text { zone }\end{array}$ & $\begin{array}{l}\text { Co. } \\
\text { Ex. }\end{array}$ & $\begin{array}{l}44.5 \pm 18.9 \\
36.5 \pm 10.0\end{array}$ & $\begin{array}{l}92.0 \pm 23.9 \\
97.0 \pm 37.1\end{array}$ & $\begin{array}{l}57.5 \pm 22.5 \\
53.0 \pm 21.1\end{array}$ & $\begin{array}{l}26.5 \pm 9.4 \\
25.0 \pm 5.3\end{array}$ & $\begin{array}{l}51.5 \pm 19.4 \\
62.0 \pm 17.5\end{array}$ & $\begin{array}{l}54.5 \pm 13.0 \\
44.5 \pm 17.9\end{array}$ \\
\hline $\begin{array}{l}\text { Hyper. } \\
\text { zone }\end{array}$ & $\begin{array}{l}\text { Co. } \\
\text { Ex. }\end{array}$ & $\begin{array}{l}67.0 \pm 10.6 \\
46.0 \pm 9.7^{* *}\end{array}$ & $\begin{array}{l}223.0 \pm 39.5 \\
160.0 \pm 29.4^{\text {** }}\end{array}$ & $\begin{array}{c}137.0 \pm 32.0 \\
74.0 \pm 22.2^{* *}\end{array}$ & $\begin{array}{r}10.0 \pm 10.5 \\
4.0 \pm 5.2\end{array}$ & $\begin{array}{l}59.5 \pm 11.2 \\
41.5 \pm 15.3^{* *}\end{array}$ & $\begin{array}{l}36.5 \pm 25.6 \\
7.0 \pm 8.2^{* *}\end{array}$ \\
\hline Total & $\begin{array}{l}\text { Co. } \\
\text { Ex. }\end{array}$ & $\begin{array}{l}174.0 \pm 28.3 \\
127.0 \pm 22.0^{* *}\end{array}$ & $\begin{array}{l}443.0 \pm 45.0 \\
338.0 \pm 52.3^{* *}\end{array}$ & $\begin{array}{l}261.0 \pm 51.6 \\
176.0 \pm 36.5^{* *}\end{array}$ & $\begin{array}{l}81.0 \pm 17.1 \\
66.0 \pm 9.9^{*}\end{array}$ & $\begin{array}{l}185.5 \pm 37.9 \\
181.0 \pm 51.2\end{array}$ & $\begin{array}{l}172.0 \pm 44.4 \\
118.5 \pm 38.8^{*}\end{array}$ \\
\hline
\end{tabular}

*, ** : 危険率 $5 \%, 1 \%$ で有意 数字は M. \pm S.D.

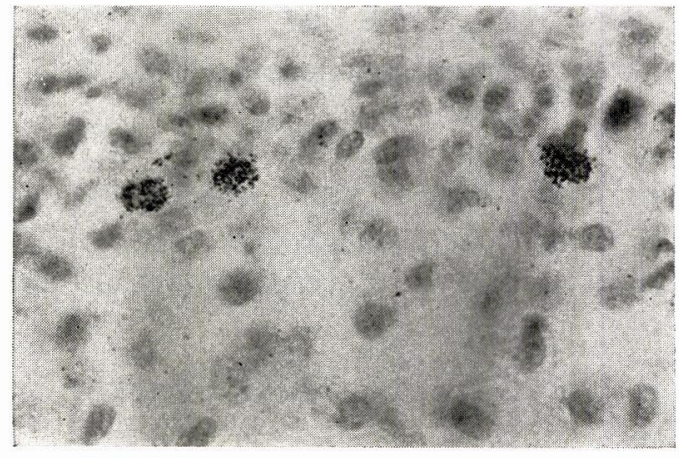

図 $9{ }^{3} \mathrm{H}$-thymidine による標識細胞

での減少がとくに著しく，3 領城の平均化の傾向 がみられた。

ここで，各領域各層における軟骨細胞あたりの 基質内線維形成量の大小を比較するために，各領 域各層の細胞数に対する銀粒子数の 割合について 検討したところ，図13，表 5 に示すような結果が

\section{Labelling Index}

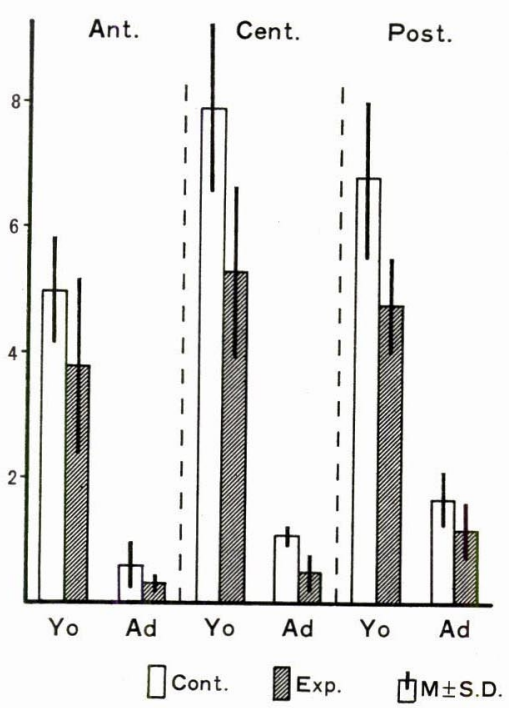

図 10 標識指数の変動

表 3 標識指数の変動

\begin{tabular}{l|c|c|c|c|c|c}
\hline \multirow{2}{*}{} & \multicolumn{3}{|c|}{ YOUNG } & \multicolumn{3}{c}{ ADULT } \\
\cline { 2 - 6 } & Ant. & Cent. & Post. & Ant. & Cent. & Post. \\
\hline Cont. & $5.0 \pm 0.9$ & $7.9 \pm 1.7$ & $6.8 \pm 1.3$ & $0.6 \pm 0.5$ & $1.1 \pm 0.1$ & $1.7 \pm 0.4$ \\
Exp. & $3.8 \pm 1.5$ & $5.3 \pm 1.4^{*}$ & $4.8 \pm 0.8^{*}$ & $0.3 \pm 0.1$ & $0.5 \pm 0.3^{* *}$ & $1.2 \pm 0.4$
\end{tabular}

*, ** : 危険率 $5 \%, 1 \%$ で有意 数字は M.土S.D. 


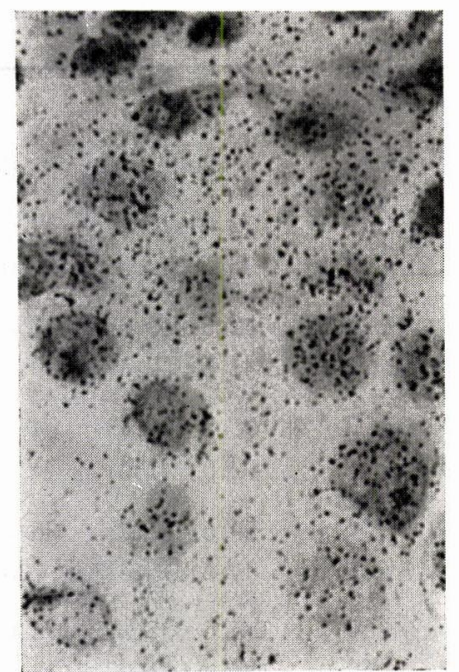

図 11 軟骨への ${ }^{3} \mathrm{H}$-proline の取込みを示す銀粒子

得られた。

すなわち，幼若個体では，中央部，後方部の細 胞の線維形成量が多く，層別には，transitional zone で最も多く, embryonic zone, hypertrophic zone，の順に少なくなっている。一方，成熟個体 においては，幼若個体に比へ，各領域，各層で細 胞の線維形成量の減少がみられ，特に中央部，後 方部での減少が著しく，細胞の線維形成量に関し ても， 3 領域間の平均化が認められた。

e. Chondroclast の出現数（図14，15, 表 6) Erosion zone における chondroclast は, 幼若

\section{Number of Grains ( ${ }^{3} \mathrm{H}$-proline)}

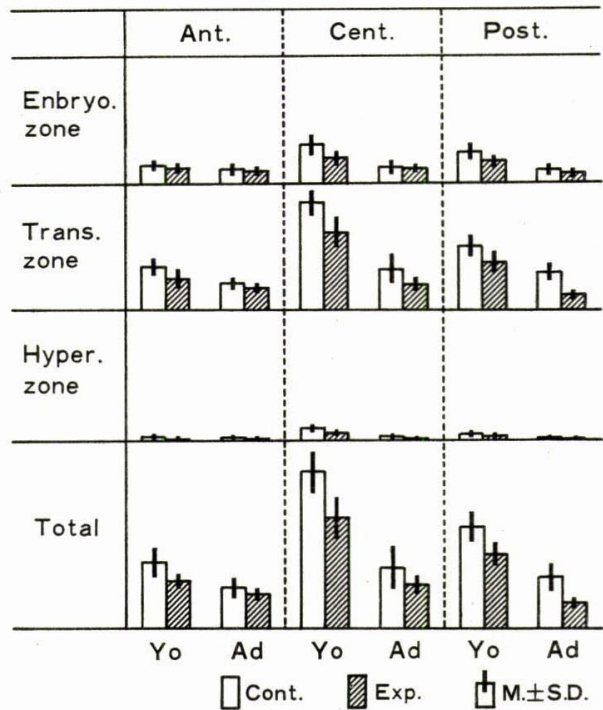

図 12 下䫟頭軟骨各層における銀粒子数 $\left({ }^{3} \mathrm{H}-\right.$ proline)

個体により多く出現しており，成熟個体において は，その約 $1 / 3$ の出現数を数えた。また，幼若， 成熟個体共に領域による出現数の 差は余り認めら れなかった。

2)、幼若個体ならびに成熟個体実験群における 所見

両個体共，すべての実験群において，下顎頭の

表 4 軟骨各層における銀粒子数 ( ${ }^{3} \mathrm{H}-$ proline)

\begin{tabular}{l|c|c|c|c|c|c|c}
\hline \multirow{2}{*}{} & \multirow{2}{*}{} & \multicolumn{3}{|c|}{ YOUNG } & \multicolumn{3}{c}{ ADULT } \\
\cline { 3 - 9 } & & Ant. & Cent. & Post. & Ant. & Cent. & Post. \\
\hline \multirow{2}{*}{$\begin{array}{l}\text { Embryo. } \\
\text { zone }\end{array}$} & Co. & $609 \pm 107$ & $1235 \pm 310$ & $977 \pm 265$ & $455 \pm 134$ & $528 \pm 207$ & $410 \pm 144$ \\
\hline Ex. & $482 \pm 109$ & $801 \pm 213^{*}$ & $712 \pm 156$ & $387 \pm 81$ & $509 \pm 115$ & $323 \pm 81$ \\
Trans. & Co. & $1378 \pm 332$ & $3448 \pm 380$ & $2049 \pm 341$ & $850 \pm 222$ & $1315 \pm 451$ & $1186 \pm 279$ \\
zone & Ex. & $997 \pm 301$ & $2515 \pm 556^{*}$ & $1525 \pm 351^{*}$ & $710 \pm 135$ & $853 \pm 187$ & $456 \pm 41^{* *}$ \\
\hline Hyper. & Co. & $127 \pm 36$ & $378 \pm 102$ & $188 \pm 46$ & $35 \pm 5$ & $83 \pm 17$ & $46 \pm 24$ \\
zone & Ex. & $51 \pm 22^{*}$ & $213 \pm 87^{*}$ & $108 \pm 59^{*}$ & $39 \pm 17$ & $45 \pm 19^{*}$ & $21 \pm 15^{*}$ \\
\hline \multirow{2}{*}{ Total } & Co. & $2114 \pm 431$ & $5061 \pm 685$ & $3214 \pm 493$ & $1340 \pm 320$ & $1926 \pm 641$ & $1642 \pm 421$ \\
& Ex. & $1530 \pm 245^{*}$ & $3529 \pm 705^{*}$ & $2345 \pm 398^{*}$ & $1136 \pm 175$ & $1407 \pm 277$ & $800 \pm 116^{*}$
\end{tabular}

*, ** : 危険率 $5 \%, 1 \%$ で有意 数字は M. \pm S.D. 
Number of Grains per Cell

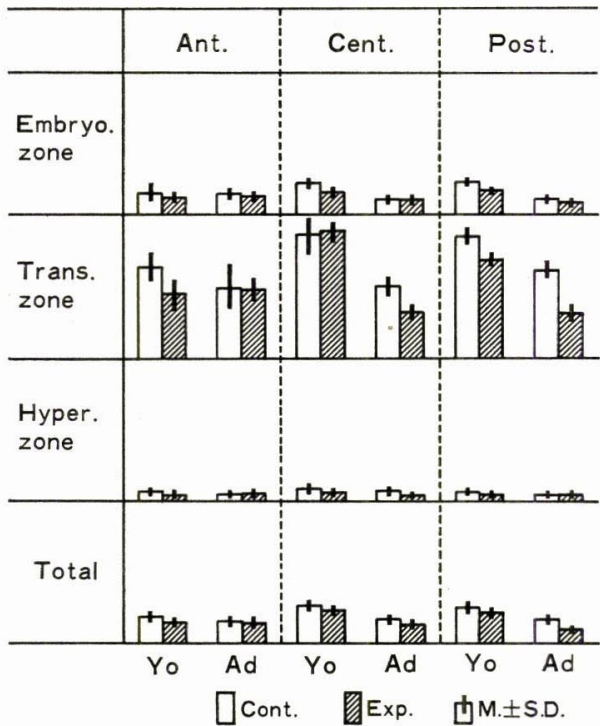

困 13 軟骨各層における細胞当りの銀粒子数 ( ${ }^{3} \mathrm{H}$-proline)

病的な組織所見は，HE 染色による組織学的検討 では，全く認められなかった。

a. 軟骨細胞数（図 7, 表 1)

対照群に比し，幼若個体実験群では各領域各層 における細胞数はわずかに減少の傾向を示した が,有意の差を示した部位は中央部の transitional zone のみであった。一方，成熟個体実験群では hypertrophic zone の後方部においてのみ有意の
減少がみられた。

b. 軟骨層厚径（図 8 , 表 2 )

幼若個体実験群では全般に各領域，各層で厚径 減少が認められたが，とくに hypertrophic zone の減少は著しく, 前方部, 中央部で約 $30 \%$, 後方 部で約 $45 \%$ の減少をみた（図16）。しかし，transitional zone での減少はほとんど認められなかっ た。

一方，成熟個体実験群 で は，幼若個体 と 同様 に, hypertrophic zone で減少を示し, 中央部で $30 \%$, 後方部で $70 \%$ の減少であった。しかし, 他 の層ではほとんど変動が認められなかった。

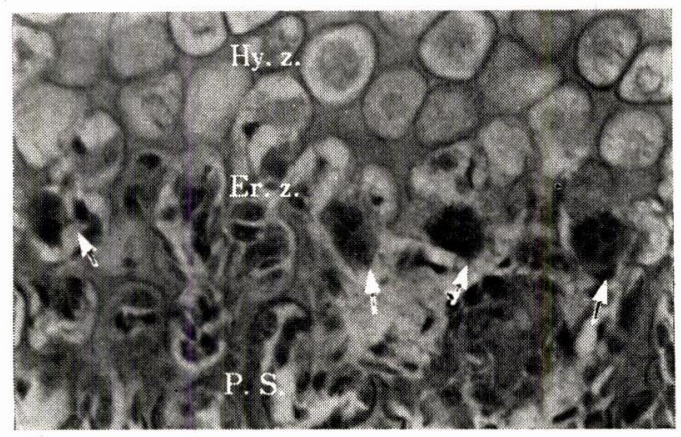

図 $14 \mathrm{HE}$ 染色標本にみられた chondroclast.

Hy. Z.: Hypertrophic zone

Er. Z. : Erosion zone P. S. : Primary spongiosa 矢印は chondroclast を示す

表 5 軟骨各層における細胞当りの銀粒子数の変動 ( ${ }^{3} \mathrm{H}-$ proline)

\begin{tabular}{l|c|c|c|c|c|c|c}
\hline \multirow{2}{*}{} & \multirow{2}{*}{} & \multicolumn{3}{|c|}{ YOUNG } & \multicolumn{3}{c}{ ADULT } \\
\cline { 3 - 9 } & & Ant. & Cent. & Post. & Ant. & Cent. & Post. \\
\hline Embryo. & Co. & $6.9 \pm 2.5$ & $10.0 \pm 1.1$ & $10.8 \pm 1.5$ & $6.7 \pm 1.2$ & $4.8 \pm 0.8$ & $5.0 \pm 0.8$ \\
zone & Ex. & $5.4 \pm 1.3$ & $7.1 \pm 1.2^{*}$ & $7.7 \pm 1.4^{*}$ & $5.9 \pm 0.8$ & $4.9 \pm 0.8$ & $3.8 \pm 0.7^{*}$ \\
\hline Trans. & Co. & $28.7 \pm 4.6$ & $39.1 \pm 6.0$ & $38.5 \pm 2.1$ & $22.7 \pm 6.3$ & $22.9 \pm 2.0$ & $28.1 \pm 2.7$ \\
zone & Ex. & $20.7 \pm 4.1$ & $39.9 \pm 3.0$ & $31.1 \pm 1.8^{*}$ & $22.4 \pm 3.1$ & $15.1 \pm 2.3^{*}$ & $14.5 \pm 2.5^{* *}$ \\
\hline Hyper. & Co. & $3.2 \pm 0.6$ & $3.8 \pm 0.5$ & $2.9 \pm 0.8$ & $2.1 \pm 0.4$ & $2.3 \pm 0.6$ & $2.0 \pm 0.4$ \\
zone & Ex. & $2.1 \pm 0.9 *$ & $2.9 \pm 0.9 *$ & $2.2 \pm 0.9$ & $2.3 \pm 0.6$ & $1.8 \pm 0.6$ & $2.2 \pm 1.0$ \\
\hline \multirow{2}{*}{ Total } & Co. & $8.3 \pm 1.3$ & $12.3 \pm 1.6$ & $11.7 \pm 1.7$ & $7.3 \pm 1.2$ & $7.9 \pm 1.2$ & $7.9 \pm 0.9$ \\
& Ex. & $6.9 \pm 0.8$ & $10.4 \pm 1.4$ & $9.7 \pm 1.3$ & $6.9 \pm 0.7$ & $6.2 \pm 0.7^{*}$ & $4.4 \pm 0.4^{* *}$
\end{tabular}

*, ** : 危険率 $5 \%, 1 \%$ で有意 数字は M. \pm S.D. 


\section{Number of Chondroclasts}

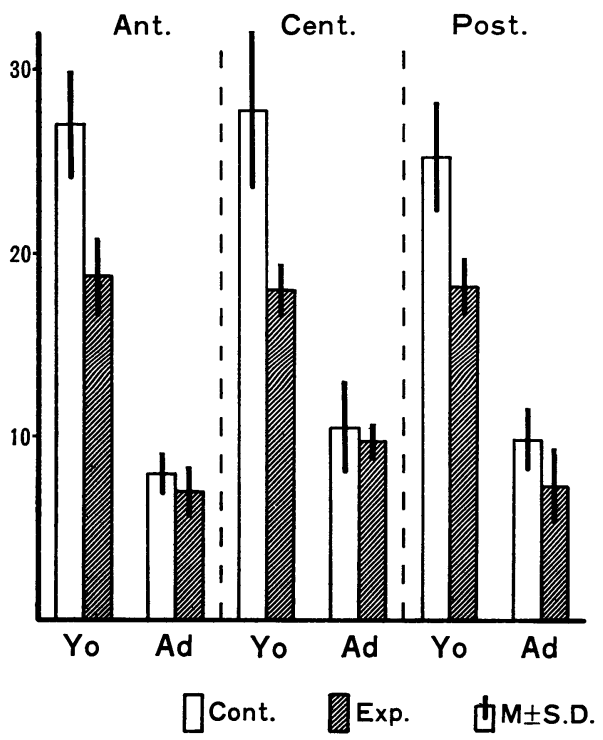

図 15 Erosion zone における chondroclast 出現 数の変動

c. ${ }^{3} \mathrm{H}$-thymidine による標識指数（図10，表 3)

幼若個体，成熟個体共に，全領域で標識指数の 低下がみられ，幼若個体では，とくに中央部，後 方部で，成熟個体では中央部で著しく低下してお り，対照群との間に有意差が認められた。

d. ${ }^{3} \mathrm{H}$-proline 取込みによる銀粒子数（図12， 表 4)

幼若個体では，各層，各領域で銀粒子の減少が 観察された。銀粒子を最も多く含む transitional zone では中央部, 後方部で対照群と有意の差が 示されたが，前方部では有意差が認められなかっ た。
一方，成熟個体では，後方部 transitional zone で著明な減少が認められるが，全般に変動は少な かった。

各層中の細胞あたりの銀粒子数についても幼 若，成熟個体共に，全般に減少の傾向を示した が，幼若個体の中央部 transitional zone では対 照群との差が他部位に比べてきわめて小さく， ほ とんど差を認められなかったのに反し，成熟個体 ではこの中央部抆よ゙後方部の transitional zone で減少が最も著しく，他部位での変動はほとんど 認められなかった。

e. Chondroclast の出現数（図15，表 6 ）

幼若個体では, 前方部, 中央部, 後方部の 3 領 域に, 成熟個体では前方部と後方部に対照群に対 し有意差のある減少が示された。しかし，成熟個 体における減少の程度は, 幼若個体に比して, は るかに軽度であった。

\section{IV. 考察}

1. 実験方法に関する考察

1）斜面板の効果について

下顎頭の成長のメカニズムを知るために，ホル モンやビタミンなどの内的刺激 ${ }^{11,12,13,14)}$ ，および 外力や咬合の変化などの外的刺激 $1,7,8,16,17,18)$ が下 影頭の成長に及ぼす影響について検討した 実験的 研究は，これまでにも数多く報告されている。

本実験では下顎頭軟骨の成長に 影響を及ぼすと 思われる外的刺激として，斜面板を用いることに より下顎の後方変位を計ったが，その結果，頭部 X線規格写真に示されたように，幼若ラット，成 熟ラット共に著明な over jet の増大を認め，か つ，臼歯部で下顎の遠心咬合を示したことが確認 された。しかし，このように両個体に認められた

表 6 Chondroclast の出現数の変動

\begin{tabular}{l|c|c|c|c|c|c}
\hline \multirow{2}{*}{} & \multicolumn{3}{|c|}{ YOUNG } & \multicolumn{3}{c}{ ADULT } \\
\cline { 2 - 7 } & Ant. & Cent. & Post. & Ant. & Cent. & Post. \\
\hline Cont. & $26.9 \pm 2.9$ & $27.8 \pm 4.4$ & $25.2 \pm 3.1$ & $8.0 \pm 1.2$ & $10.5 \pm 2.7$ & $9.8 \pm 1.7$ \\
Exp. & $18.7 \pm 2.3^{*}$ & $18.0 \pm 1.5^{*}$ & $18.2 \pm 1.6^{*}$ & $9.0 \pm 1.4^{*}$ & $9.7 \pm 1.1$ & $7.3 \pm 2.1^{*}$
\end{tabular}

\footnotetext{
* : 危険率 $5 \%$ で有意 数字は M.土S.D.
} 
A

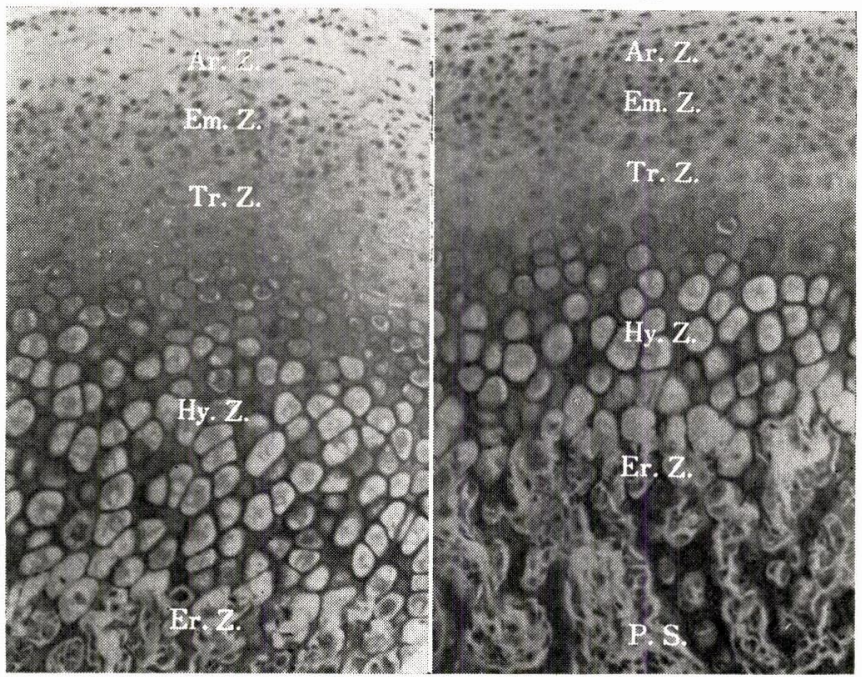

図 16 幼若ラツト下顎頭軟骨中央部の HE 染色標本 A は対照群, B は実験群を示す

Ar. Z.: Articular zone

Em. Z.: Embryonic zone

Tr. Z. : Transitional zone

Hy. Z. : Hypertrophic zone

Er. Z.: Erosion zone

P. S. : Primary spongiosa
下頂遠心咬合には，その成り立ち方に各々異なっ た要素が含まれているように考えられる。

すなわち，幼若ラットにおいては，斜面板を装 着した 10 日間に，下顎全体の後方変位は余り認め られず，下顎後縁は対照群のそれとほぼ一致して 抢り，かつ，前歯部 over jet のみが増大を示し た。このことから，幼若ラットにおいては，斜面 板の作用により下顎の前方への成長が妨げられて いる期閒中に，上顎部が対照群とほぼ同様な前方 成長を示し，その結果，症状として下颚遠心咬合 を示したものと考えられる。一方，成熟ラットに おいては，実験期間中に頡顔面の成長はほとんど 認められなかったが，下䫈後縁の後方へのずれ と, 前歯部 over jet の増大が観察された。この 事実から成熟個体においては，斜面板によって下 顎骨は強制的に後方に変位を余儀なくされ，その 結果，下顎遠心咬合が成立したものと解釈され る。従って幼若個体と成熟個体との間には症状と
しては下頡遠心咬合を示す結果となったが，その 成り立ちは異なった過程を経たことになる。

しかし，いずれにしても本実験の目的とする外 的刺激を下顎頭に与え，その部の軟骨細胞への影 響を観察する上では，十分目的を達したものと考 えてよいだろう。

しかし，本研究は，いわば短期間の外的刺激に 対寸る下頢頭の初期反応を観察検討しているの で，長期にわたる外的刺激の影響の観察や，軟骨 細胞の life span を考慮に入れた 経時的検討も必 要であろう。一方，ホルモン，ビタミンなどの内 的刺激による影響をも考慮した研究も将来必要で あると考える。

2）計測ならびに分析方法について

本実験において下顎頭軟骨層の取り扱い方は野 口の方法に従った。もともと軟骨各層の分類法や 命名法は研究者により多少異なっており，Collins ら (1946) ${ }^{111}$ は軟骨表層より, zone of embryonic 
cells, intermediate zone, zone of vacuolated cells, zone of erosion の 4 層に分類しており, Blackwood (1966) ${ }^{4)}$ は articular zone, intermediate zone, hypertrophic zone の 3 層に分類 した。また野口 $(1969)^{7)}$ は軟骨層をさらに細分化 し，表層より articular zone, embryonic zone, transtional zone, hypertrophic zone, erosion zone の 5 層に分類した。野口の 分類による 5 層 は各層間で明らかに細胞形態上の相違を示してお り容易に識別しうる。しかも細胞の形態上の違い は各層の機能と密接な 関係を有するものと思われ るので, 軟骨細胞の機能を詳細に把握する本研究 のような観点に立てば，野口により提起された分 類方法の採用が最も適していると考えた。

ところで，下㖽頭を 5 層に分類したとはいえ， 下顎頭軟骨の厚径や細胞数，細胞増殖率は，下顎 頭における前方部，中央部，後方部の 各領域間 で相違があることは，これまでにも報告されて いる。従って, 外的刺激を下䫟頭に与えた場合に も, その刺激の与え方によって, 当然, 各領域の 反応も異なってくることは想像に難くない。

本実験のように，下顎遠心咬合を斜面により誘 起させた際の下䫟頭軟骨の反応も，計測部位を前 方部，中央部，後方部の 3 領域に区分し観察する ことは, 外的刺激に対する反応を詳細に知る上で 有効な方法と思われる。

さて，分析方法のうち，標識指数の算定にあた って，オートラジオグラム上のバックグラウンド 補正法は千葉の方法に従った。この方法は確率論 に基づいたものであり，従来の補正法よりも簡便 でしかも精度の高いものといわれている。また， ${ }^{3} \mathrm{H}$-proline による銀粒子数算定の際の補正は，ア イソトープ非投与群から得られたオートラジオグ ラム上の平均銀粒子数を差し引いて補正する一般 的な方法を用いたが，各層における厚径や細胞の 大きさに相当の差異がみられるので，各層におけ る ${ }^{3} \mathrm{H}$-proline の取込みを把握するために, 各層 別にバックグラウンド補正を行なった。これによ り，各層における ${ }^{3} \mathrm{H}$-proline の取込みが適確に 把握されたものと考えられる。
2. 実験結果に関する考察

1）実験動物の体重変化について

実験期間中，幼若個体では，対照群，実験群と もに同様な増加傾向を示したのに対し，成熟個体 では実験群はほとんど体重増加を示さず, 時間の 経過と共に対照群との差は大きくなった。この両 個体にみられた体重変化の違いは両個体の外的刺 激に対する順応性の相違に基づくものと解釈され よう。すなわち, 幼若個体においては, 斜面板に よる外的刺激に対し，下顎関節部および下顎骨自 体の成長変化のみで対応したような結果が, 頭部 X線規格写真上で知られた。そして, 対照群と実 験群とに体重の 差を認めないということは，外的 刺激はストレスとして全身的な湾化をなんら誘発 するに至らない刺激量のように思われる。他方, 成熟個体においては，斜面板による外的刺激に対 し，下顎の遠心変位という局所的な反応では対応 しきれず，ストレスとして全身的な反応で応答し たように思われる。その一つの表現型として体重 の増加が抑えられ，対照群との間の差違が生じた ものと解釈できょう。

この点では，幼若個体と成熟個体に対して同じ ような外的刺激を与えたように見えても，刺激量 としては，かなりの違いがあるので，今後のこの 種の研究において検討されるべき事柄であろう。

2）下顎頭軟骨各層の成長発育について

幼若および成熟個体の対照群における 所見をも とに各層について考察してみよう。

a. Articular zone

下顎頭軟骨の最表層を被う articular zone 内 には，細胞成分が非常に少なく，線維成分が多量 に含まれている。

Blackwood $(1966)^{4)}$ および Joondeph $(1972)^{199}$ は， ${ }^{3} \mathrm{H}$-thymidine による標識細胞が articular zone には非常に少ないことを観察し，この層の 細胞増殖は下顎頭軟骨の成長には関与せず，むし ろ層内での細胞の新陳代謝にのみ働いていると推 察している。

本研究においても，幼若個体，成熟個体共に articular zone 中の細胞には ${ }^{3} \mathrm{H}$-thymidine 取込 
みがほとんど認められず，さらに， ${ }^{3} \mathrm{H}$-proline の 取込みもほとんど観察されなかった。これは，こ の層内での細胞成分, 線維成分の新生がわずかで あり，下顎頭軟骨の成長に直接関与しているとは 認めがたく，むしろ幼若，成熟個体共に軟骨の表 面をカバーし，外的刺激から軟骨を保護する役目 を果しているものと思われる。

b. Embryonic zone

Embryonic zone 中には, ヘマトキシリンに濃 染する棈円状の核を持つ扁平な細胞が，その長軸 を軟骨表面に平行にして密に並んでいるが，その 細胞形態は，成熟個体では幼若個体よりもさらに 圧平された形を示し，核質の塩基好性が上昇し， 核濃縮の様相を呈しており, 細胞活性の低下や, 細胞の老化を思わせる。しかし，この層における 細胞数は, 幼若, 成熟個体共, 全軟骨層中最も多 く, 成熟度の違いによる差異は少ないようであ る。

Embryonic zone における細胞増殖活性が下顎 頭成長に果たす役割の重要性については, 多数の 研究者により論じられているが，Folke and Stallard $(1966)^{6)}$ は，下顎の成長が embryonic zone の細胞増殖によりコントロールされているようで あると報告している。

本研究対照群でみられた ${ }^{3} \mathrm{H}$-thymidine の取込 みは幼若個体，成熟個体共に，ほぼこの層内に限 局しており，従来の報告で述べられているよう に，軟骨における細胞増殖は，主にこの層で行な われていることが確認された。

幼若個体の標識指数は下顎頭軟骨中央部, 後方 部で高い值を示し, embryonic zone における細 胞増殖が，この部位での下顎頭軟骨の旺盛な成長 に関与していることを思わせる。一方, 成熟個体 における標識指数は, 幼若個体に比し, 著しい低 下を示している事実から，Kanouse ら (1969) ${ }^{5}$ も述べているように, embryonic zone における 細胞増殖は，個体の成長がほぼ停止すると共に急 速に減少し，それまで下顎頭軟骨の成長を推進し てきた細胞増殖も，単に組織維持のためのものへ と，その役割を変えてきていると考えられる。
Embryonic zone における ${ }^{3} \mathrm{H}$-proline 取込み を示す総銀粒子数，および細胞あたりの銀粒子数 は, 幼若, 成熟個体各対照群で，全軟骨層のうち transitional zone に次いで多く，軟骨基質内線維 形成にもこの層が大きく貢献していることがうか がわれる。さらに，領域別の総銀粒子数，細胞あ たり銀粒子数は，幼若個体において，中央部，後 方部で多く，成長のほぼ停止した成熟個体におい ては, 中央部, 後方部の減少が大きく, 全領域の 平均化が認められる。このことから, embryonic zone での軟骨基質内線維形成が，同層の高、細 胞増殖率と相まって, 下顎頭の成長に少なからず 貢献しているものと推察される。

c. Transitional zone

この層に入ると細胞の形態はしだいに丸みを帯 びて円形に近づき，細胞質が増大する一方で，軟 骨基質の大幅な増加も見られ，個々の細胞が基質 内に点在するようになる。成熟個体では, 幼若個 体に比し, 細胞数が減少し, 基質成分の占める割 合が更に増大するようなにる。また，成熟個体に おいては，この層の厚径が 全軟骨層中最大とな り, hypertrophic zone で象徴される幼若個体軟 骨とは異なった層構成を示している。

機能面では, 糖タンパク複合体, およびュラー ゲン線維の生成により基質形成の場として重要視 されている transitional zone は，弾力のある基 質を多量に含んでいることから，耐圧にも大きな 意義を有する層であるように考えられる。

本研究において, 幼若, 成熟各個体対照群の transitional zone 中にみられた ${ }^{3} \mathrm{H}$-thymidine による標識細胞は非常に少なく, これに反し， ${ }^{3} \mathrm{H}$ proline 取込みによる銀粒子数は, 全軟骨層中の 60 〜 70\%を占め，さらに，この層中の細胞あたりの 銀粒子数も他層より圧倒的に多い。従って，これ らの事実より, transitional zone が細胞増殖より も基質形成面で重要な働きをしていることが 裏付 けられた。

Transitional zone 内への ${ }^{3} \mathrm{H}$-proline の取込み による総銀粒子数，および，この層中の細胞あた りの銀粒子数は, 幼若個体では下顎頭軟骨の中央 
部，後方部に多く数えられ，この領域での基質内 線維形成が活発に行なわれているように思われ る。一方, 成長のほぼ停止した成熟個体では, 幼 若個体に比し, 中央部, 後方部での減少が著し く，3 領域間の平均化がみられた。この事実は, transitional zone 内での基質形成が embryonic

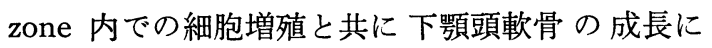
大きく関与していることを意味するものと思われ る。

\section{d. Hypertrophic zone}

この層へ進むと各細胞はますます肥大して円形 に近づき， 細胞周囲のわずかな基質を介して相互 に接して並ぶようになる。核は空胞化しているも のが多くみられ, 染色性が非常に悪く, 周囲の基 質が石灰化するにつれて, やがて細胞は変性に陥 る。

幼若個体の軟骨中に占める hypertrophic zone の割合は非常に大きく，とくに中央部，後方部と いった成長が急速に行なわれていると思われる領 域に相当して, 層の厚い hypertrophic zone が観 察された。一方，成熟個体においては，個々の細 胞は幼若個体に比して小型化し，細胞周囲にかな りの基質が残存した形をとっている。また, hypertrophic zone 内の細胞数および層厚径は, 幼若個 体に比し共に極端に減少しており, 全軟骨層中 最小の層となっている。Hypertrophic zone が個 体の年齢がさらに進むにつれて，ついには消失し

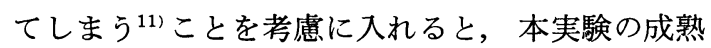
個体における hypertrophic zone が，近い将来， 消失する運命にあり，この層の下顎頭の成長に果 たす役割は，その成長の減少と共に少なくなって いるものと推察される。

下顎頭軟骨における軟骨基質の石灰化は, longbone の epiphysis にみられるような柱状形式で はなく，網目状の不規則な形を示す。

基質の石灰化について, Jibril(1967) ${ }^{20)}$ は hyper trophic zone 中にムコ多糖体を変化させ，軟骨基 質を石灰化させうる 酵素が 存在すると報告し, Dziewiatkowski ら $(1963)^{21,22)}$ は, 石灰化に先立 って hypertrophic zone 中で糖-タンパク 複合体
が酵素により分解されると述べている。また， Kuettner ら (1968) ${ }^{23)}$ は, preosseous cartilage での lysosome の分離に成功した報告を行なって いる。これらの報告で示されるように，一般に hypertrophic zone は軟骨基質の石灰化と密接な 関係を持つ層であるといわれている。

本研究で観察されたごとく, hypertrophic zone 中の細胞には，個体の幼若，成熟を問わず ${ }^{3} \mathrm{H}-$ thymidine の取込みはなく, 細胞増殖能は全くな いものと考えられ，さらに ${ }^{3} \mathrm{H}$-proline の取込み がごくわずかで，基質内線維形成能もほとんどな いと思われ，むしろ，基質の石灰化や， primary spongiosa の形成に重要な意義を有していると推 察される。

e. Erosion zone

肥大した軟骨細胞は，周囲の基質石灰化に伴な い，変性し死に至り，やがて基質と共に吸収され るが，幼若個体においては，石灰化した基質の一 部は，ひきつゔき形成される primary spongiosa の母体となり，骨化する。一方，成熟個体におい ては, hypertrophic zone の著しい減少のため, 幼若個体にみられるような primary spongiosa 経る骨稜形成様式は示さず，軟骨基質がそのまま 骨化し，骨組織に移行していく像が見受けられ， primary spongiosa の形成は起らない。

Erosion zone の 周辺には, 多数の 間葉性細胞 がみられ，血管の侵入や, 多核巨細胞である chondroclast や, Osteoblast 等の出現が観察される。 さらに, この領域での ${ }^{3} \mathrm{H}$-thymidine による標識 細胞と ${ }^{3} \mathrm{H}$-proline 取込みを示す 銀粒子数は, 共 に非常な多数にのぼり，この領域における remodeling の激しさを物語っている。

Erosion zone に打渐骨の破壊, 吸収につ いては，次のような興味ある報告がなされてい る。すなわち, Schenk ら $(1967)^{24)}$ によれば, epiphyseal plate の軟骨吸収は 2 つのメカニズム により営まれており，肥大細胞間の非石灰化横隔 壁は血管の侵入により, 石灰化縦隔壁は chondroclast により吸収されるという。さらに Durkin ら (1969) ${ }^{25)}$ は, 軟骨基質が柱状の石灰化を示 
す tibial epiphyseal cartilage は血管侵入により 崩壊するのに対し，軟骨細胞の周囲に網目状の石 灰化を起こす chondylar cartilage は, chondroclastにより崩壊され，2 次的に血管侵入を伴な うとしている。

Chondroclast の起源については, Kember $(1960)^{26)}$, Tonna ら (1961) ${ }^{27)}$ の研究があるが, 彼らによると, 一つの細胞の核分裂により多核形 成がなされるのではなく，複数の間葉性細胞の融 合によるものであるという。さらに，この細胞の 微細構造とその機能について, 山形ら (1969) ${ }^{28)}$ は, 電顕所見による検討から, chondroclast は石 灰化した軟骨基質部に接して, 多数のミトコンド リアと空胞を持った多核巨細胞で, 細胞膜の一部 は刷子縁を有し，基質分解に際して酸を分泌し， また，有機基質を分解する酵素も合成分泌してい ると報告している.

本実験においても，この多核巨細胞，すなわち chondroclast は, 軟骨破壞のみられる erosion zone には必ず出現しており, 眓17に示されるよう

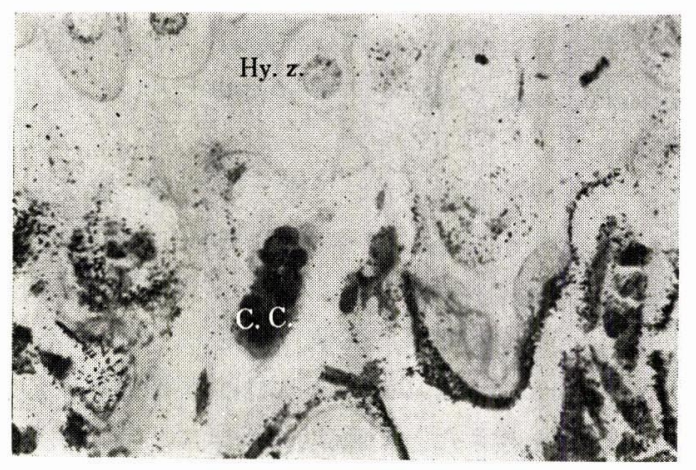

図 $17{ }^{3} \mathrm{H}$-proline 取込みと chondroclast Hy. Z. : Hypertrophic zone C. C. : Chondroclast

に，骨稜形成部には osteoblastによると思われる 骨基質の添加がみられ，その部分には ${ }^{3} \mathrm{H}$-proline 取込みによる多数の銀粒子が観察された。一方, chondroclast の存在部には ${ }^{3} \mathrm{H}$-proline の取込み がほとんどなく, chondroclast が軟骨の吸収と密 接な関係を有していることを示唆している。 成熟個体における chondroclast の出現数は,
幼若個体に比し, 著しく減少しているが, これ は, 成熟個体での hypertrophic zone の細胞数, 層厚径における著しい減少に伴なう primary spongiosa の欠如により骨髄腔が狭窄し, 軟骨吸 収が余り活発に行なわれなくなっているためと思 われる。

\section{f. 小括}

軟骨各層は，形態的にも機能的にも，その果た 寸役割は異なっていると考えられる。すなわち, articular zone は下顎頭軟骨の保護層として存在 し, 下顎頭軟骨の成長は主として embryonic zone, transitional zone での細胞増殖, 基質形成 により推進されている。また, hypertrophic zone の存在は, 成長の激しい時期に観察される primary spongiosa の形成に不可欠なものであり, 骨 稜の成長に多大な影響を与えているものと思われ る。

幼若個体軟骨の中央部, 後方部において, 細胞 数が多く, 層厚径も厚いことが観察され, さらに 細胞増殖, 基質形成の各々の活性が高いことか ら, 幼若個体の下顎頭軟骨のこの領域における成 長が旺盛であるものと推察される。一方, 成熟個 体の軟骨においては, 幼若個体に比し, 細胞数, 層厚径の減少が認められることや, 細胞増殖, 基 質形成, 基質吸収の各々の活性が著しく低下して いることから，成熟個体における下顎頭軟骨の成 長が,ほとんど行なわれていないものと推察され る。

以上考察したような各層各様の役割を考虑に入 れると, 軟骨の外的刺激もある程度推察できる。 すなわち, もしも外的刺激が下顎頭軟骨の成長に 影響力を持つものであるならば，その成長の主要 因である細胞数の増加, ならびに基質の増生に影 響を与え, 従って, embryonic zone での細胞増 殖, および, transitional zone での基質形成に何 らかの変動が生ずることになるであろうことは想 像に難くない。

さらに, 外的刺激が, 直接あるいは間接にせ よ，下顎頭の骨稜形成にまで波及するならば，骨 稜形成上不可欠である軟骨の崩壊や吸収に 影響が 
生ずることも考えられ, 従って, 当然, chondroclast の出現数にも変動が 観察されるであろう。

また, 成長のほぼ終了した成熟個体においで は，外的刺激による影響は主として組織維持のた めに行なわれている細胞増殖，基質形成，基質吸 収の各面に現われることが考えられるが，成熟個 体における各々の活性が著しく低下しているた め，外的刺激による大幅な変動は生じにくいかも 知れない。

3）下顎頭軟骨における外的刺激に対する反応 について

\section{a. Articular zone}

Articular zone における外的刺激に対する反応 は, 幼若個体, 成熟個体共に層厚径のわずかな減 少が観察されたにとどまり，ほとんど対照群との 間に有意差は認められなかった。したがって，こ の層は外的刺激に対する反応が，個体の成熟度の いかんにかかわらずきわめて少ない層といえよ う。

\section{b. Embryonic zone}

幼若個体実験群においては 標識指数の低下が中 央部, 後方部で認められたが, 細胞数の変動はほ とんどなく, embryonic zone 内軟骨細胞の transitional zone への流出速度が, やや停滞してい るものと推察される。さらに幼若個体における ${ }^{3} \mathrm{H}$-proline 取込みによる銀粒子数の中央部での減 少, ならびに細胞あたりの 銀粒子数の減少が認め られることから，外的刺激がこの層の細胞増殖の みならず，基質内線維形成にまで影響を及ぼして いることがうかがわれる。

Folke and Stallard $(1966)^{6)}$ は，下顎頭軟骨中 には embryonic zone が生涯存続し, その growth potential は成熟個体においても刺激により 賦活できるとし，さらには機械的に condylar growth を変えることにより skeletal malocclusion を治療することも可能であると述べている。

本実験の成熟個体においては，外的刺激による 細胞数，層厚径，細胞増殖，基質形成面での変動 はほとんど認められず，この層の感受性が非常に 低いことが示された。また，対照群に示されたよ
うに, 成熟個体のこの層における種々の細胞活性 が極度に低いことから，Folke and Stallard が述 ベているような成熟個体における大きな形態変化 を期待することは困難であるように思われる。し かし，本実験に用いた斜面板による刺激の程度で は，変化が認められなかったとも考えられるの で，この点については，外的刺激のレベルを，い ろいろな段階に分け，適刺激の存否を検討するこ とも今後必要であるかも知れない。

\section{c. Transitional zone}

幼若個体実験群においては, ${ }^{3} \mathrm{H}$-proline 取込み が，中央部，後方部で著しい減少をみせ，基質内 線維形成の低下を示したことより，transitional zone 内での 基質内線維形成は外的刺激により抑 制されているものと推測される。

しかしながら，ここで注目すべき点は，中央部 transitional zone 内の細胞あたりの銀粒子数が全 く変動していないという現象である。この現象に ついては, 幼若個体において, 中央部の transitional zone における個々の細胞の線維形成量は外 的刺激による変動が全くなかったにもかかわら ず, 細胞数に減少がみられたため, 中央部 transitional zone の総銀粒子数が減少したものと説明 されよう。

一方, 成熟個体においては, 中央部, 後方部で の ${ }^{3} \mathrm{H}$-proline 取込みが減じ，さらに同部での細 胞あたり 銀粒子数も著しく減少している。このこ とから, 外的刺激は成熟個体に対し, 中央部, 後 方部の transitional zone に括ける基質形成に大 きな影響を与えたといえよう。また，幼若個体， 成熟個体間にみられた中央部 transitional zone における反応の相違は, 両個体の外的刺激に対す る反応様式の違いに由来するものとして, はなは だ興味深い。

\section{d. Hypertrophic zone}

幼若個体実験群においては, 全軟骨層中, hypertrophic zone の厚径が最も著しい減少を示し, とくに中央部, 後方部での減少が著明であった。 この層の著し、厚径減少は, おそらくは, embryonic zone $\rightarrow$ transitional zone $\rightarrow$ hypertrophic zone 
という細胞の流れが，外的刺激により影響を受け $\tau$, transitional zone からの流入細胞と erosion zone での軟骨吸収とのバランスが崩れたためと思 われる。また，この層内の個々の細胞が極端に肥 大しているため，わずかな細胞数の変動も大きな 厚径の変動となって現われるのであろう。

一方，成熟個体実験群に打いても，形態上は hypertrophic zone の厚径減少が 全軟骨層中最も 著明であり，時にはこの層の消失さえ観察される こともあったが，幼若個体に比し，その変動量は ずっと少ないものであった。”従って幼若個体にみ られたような，外的刺激による全軟骨層厚径の著 明な減少が認められなかったものと思われる。

e. Erosion zone

幼若個体実験群においては， erosion zone 内に みられる chondroclast の出現数は, 対照群に比 し大幅に減少していたことから，外的刺激が軟骨 吸収能に大きな影響を及ぼしているものと思われ る。一方，成熟個体実験群においては，chondroclast の出現数は若干の減少を示した程度であり， 幼若個体に比して，外的刺激による影響をあまり 受けていないようである。

\section{f. 小括}

幼若個体実験群の下䫟頭軟骨に認められた反応 として，形態的には，軟骨層全体の厚径減少，と くに全軟骨層中最大層である hypertrophic zone の著しい縮少が主たる変化であった。また, 細胞 の機能面では，細胞増殖，基質形成，および基質 吸収の各面で著しい活性低化が生じていると思わ れ，外的刺激による影響が軟骨細胞の一連の分化 成熟過程にまで波及していることが示された。こ れらの事実は，幼若個体の下䫟頭軟骨が，外的刺 激により，その成長様式に変化をきたすという考 え $^{2,6,8,15,17)}$ に支持を与えうるものといえよう。

一方，成熟個体実験群に示された下顎頭軟骨の 細胞反応は非常にわずかなものであったが，これ は，幼若個体に比して，細胞増殖能，基質形成 能，基質吸収能の全てにおいて，基本的な活性が 著しく低下しており，加えて，外的刺激に対する 感受性が低下していることに 起因するものと思わ
れる。また，形態上の変化としては，幼若個体と 同様に hypertrophic zone の縮少が最も著明で あった。このように hypertrophic zone は, 下顎 頭の成長様相を知る上にも，また，外的刺激に対 する反応を知る上にもきわめて重要な存在といえ よう。

\section{V 総括ならびに結論}

幼若ラット，成熟ラットの下顎切歯唇面に斜面 板を装着し，その結果誘起される下顎遠心咬合に 対して，下顎頭軟骨がどのように応答するかにつ いて定量的に検討した。すなわち， ${ }^{3} \mathrm{H}$-thymidine， ${ }^{3} \mathrm{H}$-proline を用いたオートラジオグラフィー，な らびに HE 染色標本により，軟骨細胞数，軟骨 層厚径，軟骨細胞増殖，軟骨基質形成，軟骨基質 吸収の各々について検討を加え，次のような結果 が得られた。

1. 幼若，成熟個体共に，斜面板による外的刺 激を与えた場合には，下顎頭軟骨における細胞数 は，わずかな減少を示したが，全般に大きな変動 は認められなかった。

2. 外的刺激を受けた場合の下頢頭軟骨の各層 の厚径は，幼若個体では著しい減少がみられた。 それは，とくに hypertrophic zone で顕著であっ た。しかし, transitional zone の厚径は余り変 動しなかった。一方，成熟個体の厚径は hypertrophic zone に減少がわずかに観察されたにすぎ ずほとんど変動しなかった。

3. 下顎頭軟骨層のうち， ${ }^{3} \mathrm{H}$-thymidine 投与 後 1 時間でラベルされた細胞は，ほぼ embryonic zone 内に限局しており，主にこの層で細胞增殖 が行なわれていることが知られた。そこで外的刺 激を与えた場合の下顎頭軟骨の標識指数について 調べてみると，幼若個体では下頇頭軟骨中央部お よび後方部で著しい低下を認めたのに対し，成熟 個体では中央部に低下を認めたが，幼若個体にみ られたような大幅な低下はなかった。

4. 外的刺激は，軟骨細胞分裂のみならず，軟 骨基質形成にも多大の影響を与えた。すなわち， 軟骨に取込まれた ${ }^{3} \mathrm{H}$-proline による銀粒子数は， 
幼若個体では全領域で著しく減少し，基質内線維 形成の低下を示した。成熟個体では後方部で減少 が観察されたのみで，幼若個体のような大きな変 動はなかった。

5. ${ }^{3} \mathrm{H}$-proline 取込みを示す銀粒子数は，全軟 骨層中 transitional zone で最も多く，この層で 基質内線維形成が盛んに営まれていることが知ら れた。

6. Erosion zone において 軟骨の吸収に関与 していると思われる chondroclast の出現数は, 幼若個体，成熟個体共に減少した。

7. 成熟個体は幼若個体に比し，細胞増殖，基 質形成，基質吸収のすべての面で活性が著しく低 下しており，外的刺激に対する反応は幼若個体と 同様に低下を示したが，その変動量は僅少であっ た。

稿を終わるに臨み, 終始御懇篤なる御指導と御校閲を 賜わった三浦不二夫教授，黒田敬之講師に深甚なる感謝 の意を表するとともに，種々御教示，御助言いただいた 野口規久男助手に束心より感謝いたします。また本研究 に御協力下さった矯正学教室の方々に厚く御礼申上げま す。本論文の要旨の一部は第32回日本矯正歯科学会総会 に㧍てて発表した。

\section{文献}

1) Furstman, L.: The effect of loss of occlusion upon the mandibular joint. Am. J. Orthod., 51 : 245-261, 1965.

2) Stöckli, P. W. and Willert, H. G. : Tissue reactions in the temporomandibular joint resulting from anterior displacement of the mandible in the monkey. Am. J. Orthod., $60: 142-155.1971$.

3) Lemoine, C. et al. : Réaction condylienne à la déviation mandibulaire provoquée chez le rat. L' Orthodontie Française, 39 : 147-151, 1968.

4) Blackwood, H. J. J. : Growth of the mandibular condyle of the rat stadied with tritiated thymidine. Arch. Oral Biol., 11 : 493500, 1966.

5) Kanouse, M. C. : Condylar growth in rhesus monkeys. J. Dent. Res., 48 : 1171-1176, 1969.

6) Folke, L. E. A. and Stallerd, R. E. : Chondylar adaptation to a change in intermax- illary relationship. J. Period. Res., $1: 79$ 89, 1966.

7）野口規久男 : 外力を与えた際の幼若ラツト下顎 頭の研究. 口病誌, $37: 222-241,1970$.

8) Charlier, J. P. : Action of the chin cup on mandibular growth: Experimental research in the rat. L'Orthod. Franç., 40 : 99-113, 1969.

9) 花田晃治 : 頭部 $X$ 線規格写真によるラツトの顎 顔面頭蓋の成長発育に関する研究. 口病誌，43: 18-74, 1967.

10）千葉元丞：オートラジオグラフィーにおけるバ ックグラウンドの簡単な補正法 : 細胞核におけ る標識指数の測定. Radioisotopes, $19: 501-506$, 1970.

11) Collins, D. A. et al.: Growth and transformation of the mandibular joint in the rat. Am. J. Orthod. and Oral Surg., 32 : 431-451, 1946.

12) Asada, M. et al. : Effect of anteriorpituitary hormones upon condyle of rat mandible. Gumma J. Med. Sc., 4 : 285-289, 1955.

13) Meyer, J. et al. : Experimental studies on the interrelations of condylar growth and alveolar bone formation. II Effects of growth hormone. Angle Orthodont., 37 : 309-319, 1967.

14) Irving, J. T. and Durkin, J. F. : A comparison of the changes in the mandibular condyle with those in the upper tibial epiphysis during the onset and healing of scurvy. Arch. Oral Biol., 10 : 179-185, 1965.

15) Baume, L. J. et al. : Growth and transformation of the temporomandibular joint in an orthopedically treated case of Pierre Robin's syndrome. Am. J. Orthod., 45 : 901916, 1959.

16）檜山達郎：抜歯による実験的咬合変化が顎関節 に及ぼす影響に関する病理組織学的研究. 口病 誌, $35: 58-72,1968$.

17) Charlier, J. P. et al. : Effects of mandibular hyperpropulsion of the prechondroblastic zone of young rat condyle. Am. J. Orthod., 55 : 71-74, 1969.

18) Gupta, O. P. et al. : Studies on experimental malocclusion in rabbits. 1 Method of induction of malocclusion and its effects on the temporomandibular joint. Am. J. Orthod., $60: 54-67,1971$.

19) Joondeph, D. R. : An autoradiographic study of the temporomandibular articulation in the growing Saimiri sciureus monkey. Am. J. Orthod., $62: 272-286,1972$. 
20) Jibril, A. O.: Proteolytic degradation of ossifying cartilage matrix and the removal of acid mucopolysaccharides prior to bone formation. Biochem. biophys. Acta., 136 : 162-165, 1967.

21) Dziewiatkowski, D. D. and Campo, R. D. : A consideration of the permeability of cartilage to inorganic sulphate. J. biophys. biochem. Cytol., 9 : 401-408, 1961.

22) Campo, R. D. and Dziewiatkowski, D. D. : Turnover of the organic matrix of cartilage and bone as visualized by autoradiography. J. Cell Biol., 18 : 19-29, 1963.

23) Kuettner, K. E. et al. : Lysozome in preosseous cartilage. Calc. Tiss. Res., 1 : 298305, 1968.

24) Schenk, R. K. et al. : Cartilage resorption in the tibial epiphyseal plate of growing rats. J. Cell Biol., 34 : 275-291, 1967.

25) Durkin, J. F. et al. : A comparison of the circulatory and calcification patterns in the mandibular condyle in the guinea pig with those found in the tibial epiphyseal and articular cartilages. Arch. Oral Biol., 14 : 1365-1371, 1969.

26) Kember, N. F. : Cell division in endochondral ossification. J. Bone \& Joint Surg., 42 B : 824-839, 1960.

27) Tonna, E. A. and Cronkite, E. P. : Use of the tritiated thymidine for the study of the origin of the osteoclast. Nature, 190:459460, 1961.

28）山形達也ら：骨の発生, 生体の化学, 20 : 142157, 1969. 